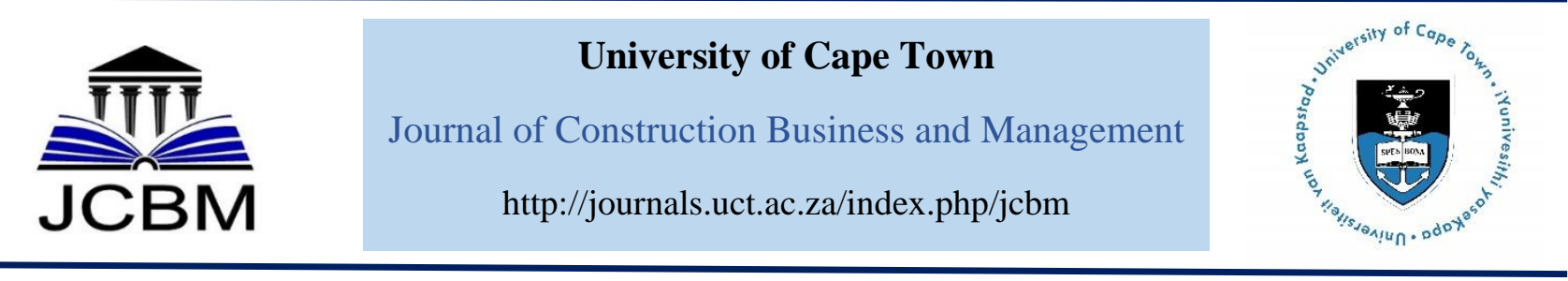

\title{
Factor's Influencing Contractors Risk Attitude in the Malaysian Construction Industry
}

\author{
D.M Taofeeq ${ }^{1}$, A.Q Adeleke ${ }^{2}$ \\ ${ }^{1,2}$ Faculty of Industrial Management, Universiti Malaysia Pahang
}

Received 12 October 2018; received in revised form 19 March 2019, 17May 2019, 7 June 2019; accepted 14 June 2019. https://doi.org/10.15641/jcbm.3.2.668

\begin{abstract}
The Malaysian construction industry often acts as a vehicle that motivates' the development of the nation's economy. The industry is commonly referred to as a catalyst for development. However, poor performance in terms of productivity and quality systems has been the main issues of discussion from most of the government reports. In order to improve performance in the Malaysian construction industry, the introduction of the Occupational Safety and Health Act (OSHA) in 1994 has made all industries in Malaysia to identify hazards, conduct risk assessment and control those risk and at the same time implement an integrated system to ensure consistency and better performance of projects in Malaysian industries. Therefore, in this paper, the ranking of specific factors affecting contractors' risk attitudes in the Malaysian construction industry was assessed. A review of relevant literature was undertaken to identify the factors influencing contractors' risk attitudes. The study found that the four leading specific factors influencing contractors risk attitude in the Malaysian construction industry are; Project Related Factors, Working capital, Human-Related Factors, and External Environment. The study confirms the individual factors that affect the contractor's risk attitudes. Knowledge of these factors will facilitate contractors' decisionmaking process and serve as a useful reference for further studies in the field of construction project management.
\end{abstract}

Keywords: Contractor's risk attitude, Malaysia, Risk attitude, Risk management

\section{Introduction}

In Malaysia, the construction industry is one of the most significant sectors that have significantly and rapidly contributed to the country's economic growth. According to the Construction Industry Development Board (CIDB) in Malaysia, the construction industry attained RM170 billion and RM180 billion value of projects in the year 2017 and 2018, respectively. The projects included the construction sector, agriculture sector, mining and quarrying sector, manufacturing sector and services sector. Implementing projects on schedule is problematic in the undefined, complex, multiparty, and dynamic environment of construction projects (CIDB, 2017). Because of this, the industry is always open to conflicts and disputes. It is common for some stakeholders claiming for imperfect work, delayed completion and changes of scope (Adeleke et al., 2018).

The CIDB Malaysia, which is an organization established with the primary function of developing, improving and expanding the Malaysian construction industry, has identified risk and other sustainabilityrelated issues as the top issues impacting the construction industry (CIDB Malaysia). Many construction projects in Malaysia in the process of initiating, planning, controlling, executing and closing have experienced high risks. Besides, the risk level during the construction phase is recognized as a risk higher than that of the economic sector. The Project Management Institute (PMI, 2008) stated that risk is an uncertain condition which has an undesirable influence on the goal of a project.

Risk management involves proactive means of combating possible future risks rather than being reactive. It is imperative to evaluate the main and common risks which could impact negatively on the goals of the construction project. To improve performance in the Malaysia construction industry, the government enacted the Occupational Safety and Health Act (OSHA) in 1994. Under this Act, all sectors in Malaysia are required to identify hazards, conduct a risk assessment and control those risk and at the same time implement an integrated system to ensure consistency and better performance of

\footnotetext{
${ }^{1}$ Corresponding Author. D.M Taofeeq

Email address: taofeeqmoshood@gmail.com
} 
projects (Razak et al., 2013). Though there is a development of safety performance and increase in safety awareness in the construction industry, the risk level is still one of the highest across all sectors.

The Contractor's risk decision making is fundamental to construction risk management. Throughout construction projects development, particularly in the design stage, the participants are challenged with huge risk decision-making problems, which are addressed through recognizing, analysing and responding to possible risks, and eventually enhancing solutions (Jarkas \& Haupt, 2015). Some researchers have identified a variety of approaches that enable a more objective risk decision-making process (Jarkas \& Haupt, 2015; JatoEspino et al., 2014; Pennings and Smidts 2017; Khan, Liew, \& Ghazali, 2014)). The most generally useful approaches comprise of the predictable profit and loss value decision technique, the decision diagram technique, the matrix decision technique, the marginal decision technique, the Bayesian decision technique, and the Markov decision technique.

Also, most of the techniques presented above, are based on the predictable value principle, which needs iterative decision-making processes for satisfactory data collection. This is because the predictable value cannot be determined from a onetime risk decision-making circumstance. Jato-Espino, et al. (2014) also established that decision makers perceive risks differently in numerous circumstances, which is compounded by factors such as engineering experience, educational background, individual beliefs, and principles. Those particular individual observations cause differences in decision making, making it impossible for people to make the right decision in all the circumstances in pursuit of maximum expected value. It is implying that the maximum expected value theory is inadequate in explaining human behaviour in the risk-decision making process (Lee et al., 2016).

According to Jato-Espino et al. (2014), contractors risk attitudes is much related to the decision maker's sensitivities. Risk attitude is a chosen state of mind with a focus on those uncertainties that could have a positive or negative impact on construction activities. Therefore, people's risk attitudes reflect their characteristics and experiences; it also reflects the economic, procedure and management environment into which they fit. Even in similar decision-making circumstances, dissimilar decision-makers would make different, sometimes even the opposite decision and judgements(Taofeeq et al., 2019). The individual judgment related to personal issues in the decision-making procedure is presented as a risk attitude, which plays a significant part in decision making. Hence, decisions that are made with no knowledge of the decision maker's risk attitude might not be dependable. However, those issues that are influencing decision makers' risk attitudes in construction projects remains unsolved. Therefore, this paper aims to identify and rank the critical factors affecting contractors' risk attitudes in the Malaysian construction industry.

\section{Literature Review}

No construction project is free of risks. These risks affect the schedule, costs, quality and in the long run, the project objectives. According to Jaskowski and Biruk (2011), the construction project is pretentious by various types of risk factors, such as accident, weather conditions, location, clients, contractors, subcontractors, staff, crew, labourers and defects affects the project. The studies of Sambas, Ivan and Soon (2007), revealed 28 main constructionrelated risks such as lack of effective communication between parties, lack of construction risk management, lack of material, unappropriated safety precautions and lack of equipment had been figured out as the primary factors. Risks related to the contractor's risk attitudes in the construction industry are broadly categorized as shown in Figure 1.

Risk management process starts with risk identification, which is identifying the type and the cause of risks. It continues by categorizing the types of risks and their impact on the project. Risk analysis will screen and import the recognized risks. Following the risk analysis, risk response design is then developed. During project operation, the risks identified, and their responses are monitored and studied (Shirolkar et al., 2017). Also, many researchers confirm that risk management is a set of procedures and tools combined with the project management processes (Kim et al., 2011; Hwang, Zhao \& Toh, 2014; Lee et al., 2015).

Adeleke et al. (2016), also revealed that risk management is one of the significant knowledge areas in the project management body of knowledge because, many parties in the project such as engineers, architects, project managers, quantity surveyors, designers, contractors, subcontractors and clients monitor the risk during the project lifecycle. Risk management is an indispensable contributor to business and project achievement since its attention to effectively addressing uncertainties to minimize pressures, maximize chances, and optimize the performance of objectives (Shirodkar et al., 2017; Abulhakim et al., 2019). Besides, construction project becomes more complex and challenging when adopting new methods for responding to risk as the contractors need to consider how to treat and which method is suitable for their organization.

However, risk response approach remains the weakest part of the risk management process, where proper management requires the identification of risks in a welldefined manner, which can only be attained when "all" parties namely, clients, consultants, contractors, authorities and policymakers, comprehend their risk responsibilities, risk event conditions and risk handling capabilities (Mhetre et al., 2016). A response is needed in every stage to review the action plan. The risk response attitudes remains the weakest part of the risk management process in Malaysia construction project, where the proper management requires a practical identification of risks in a well-defined manner, which can only be attained when "all" parties involved in the construction project, namely, clients, consultants, contractors, authorities and policymakers, comprehend their risk responsibilities, risk event conditions and risk handling capabilities (Wang, et al., 2011). 


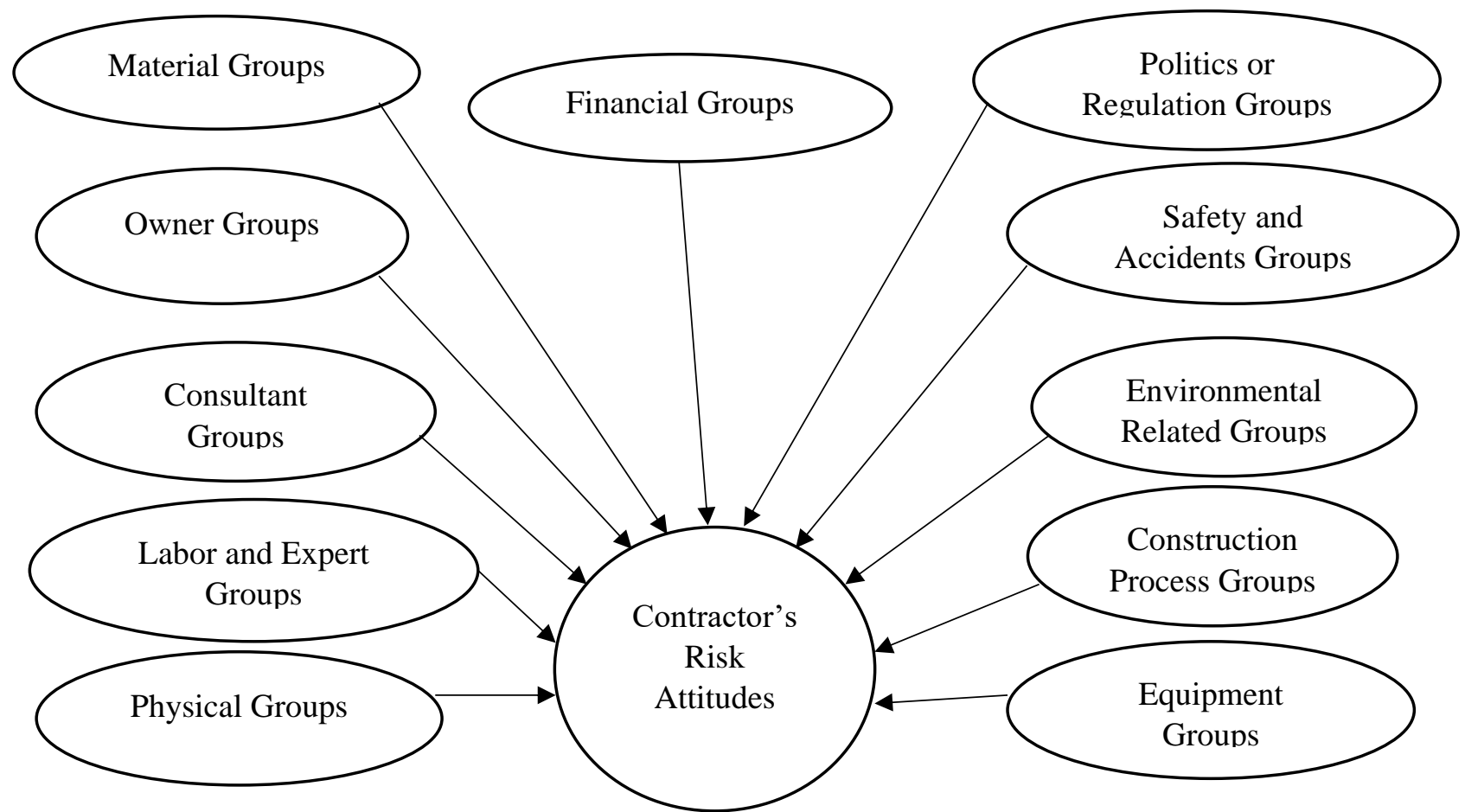

Figure.1: Risk and its environment

\subsection{Factors influencing contractors risk attitudes in the Malaysian construction industry}

Table 1 shows that the majority of the problems faced by contractors are due to resource issues (Paweł et al., 2017).

Table 1: Factors influencing contractor's risk attitudes in the Malaysian construction industry

\section{Construction Risk factors in Malaysian risk groups construction industry}

\begin{tabular}{|c|c|}
\hline Physical group & $\begin{array}{l}\text { Natural disasters } \\
\text { Land surface conditions } \\
\text { Groundwater conditions } \\
\text { Uncertainty conditions in the field }\end{array}$ \\
\hline $\begin{array}{l}\text { Labour and } \\
\text { Experts group }\end{array}$ & $\begin{array}{l}\text { Productivity and efficiency } \\
\text { Less compact teamwork } \\
\text { Argumentative workers } \\
\text { Lack of workforce } \\
\text { Labour strike } \\
\text { Design errors } \\
\text { Skills and expertise } \\
\text { Design errors }\end{array}$ \\
\hline $\begin{array}{l}\text { Consultant } \\
\text { group }\end{array}$ & $\begin{array}{l}\text { Incomplete design data } \\
\text { Late information from planners }\end{array}$ \\
\hline Owner group & $\begin{array}{l}\text { Financial Failure owner } \\
\text { Change order } \\
\text { Delay in delivery }\end{array}$ \\
\hline Material group & $\begin{array}{l}\text { Damage during shipment } \\
\text { Damage during storage } \\
\text { Low-quality material }\end{array}$ \\
\hline $\begin{array}{l}\text { Equipment } \\
\text { group }\end{array}$ & $\begin{array}{l}\text { Lack of equipment } \\
\text { Unsuitable tools due to age } \\
\text { Damage to equipment }\end{array}$ \\
\hline $\begin{array}{l}\text { Construction } \\
\text { Process group }\end{array}$ & $\begin{array}{l}\text { Changes in construction work due } \\
\text { to implementation difficulty } \\
\text { Poor quality of work }\end{array}$ \\
\hline
\end{tabular}

Communication and Coordination problems

Inappropriate method of project implementation

Access to the project site

Environmental Traffic jam

Related group

Disturbances

Lack of equipment and material storage facilities

The machine is not checked before operating

Safety and accidents group Workers do not wear protective equipment

Safety regulations are not implemented on site

Politics or Changes in government regulations

Regulation group Government policies that led to the cessation of the project Monetary instability Complicated licensing procedure Availability of funds Late payments by the owner Inflation Fluctuation

Financial The high cost of building materials group The increase in the cost of leasing equipment Higher wage than the estimate The high cost of equipment maintenance

\subsection{Contractor's risks attitudes}

According to Wang, et al. (2016), the attitude is founded on the personality's positive or negative assessment of the consequences of a specific type of behaviour, as well as own principles or knowledge about the consequences. 
Hence, numerous risk attitudes could be applied, and these would lead to different practices and outcomes (Hillson and Murray-Webster, 2007). Attitude can be described as the favourable/unfavourable moods towards a particular behaviour. Therefore, it is important to understand risk attitudes.

Some studies of risk management suggest that professional managers are relatively risk-averse; others question the assumption of global risk-aversion (Barr, \& Feigenbaum, 2014). Many studies in organization and economics found the presence of heterogeneity in risk attitudes among organizations, even in homogeneous industries (Sathishkumar, 2015; Wang et al. 2011; Wang et al. 2016; Taofeeq et al., 2019). Wang et al. (2016) also found out that some contractors in the construction industries were risk-takers because the jobs they do are much riskier than other occupations. Nevertheless, this assumption is not compelling enough. For the fact that the jobs they do are hazardous does not mean that contractors are risk-takers. Many contractors consider themselves risk-averters, not risk-takers.

Seung et al. (2005) further prove that people tend to be risk-averse in predicting project return (conventional). They also tend to seek risk in approximating project cost (theoretical), which leads to the changes in individual risk insights and also produces the systematic biases in recasting both project cost and reappearance. Furthermore, it is designated that experts qualified in a specific area tend to be less error-prone in making estimates than it is in the case of the learner group.

Study of Wang et al. (2011) revealed that the connection between attitude and decision-making behaviour had been presented in many fields as well as in the construction management area. Theory of planned behaviour by (Ajzen 2000) is a dominant model that represents the relationship between attitude and decisionmaking behaviour. In Ajzen's model, attitudes, individual norms and perceived behaviour regulator influence behavioural purposes, which in turn control the possibility of behaviour that is yet to happen.

Besides, decision making plays a significant part in construction project management. Because of the project, participants' restricted motives. According to Zhang \& Li (2015), what influences their adopted approaches are usually of more risk perception than the risk itself. The participant's judgement about risk is known as risk perception (Venkatesh et al., 2013). Chen et al. (2016) noted that a contractor's risk pricing behaviour could be affected in the decision-making process by their risk perception. However, there is limited research concerning the possibility of contractors becoming an opportunist in reducing possible loss once a high level of risk is perceived.

Furthermore, previous studies were unable to specify how the contractors' behavioural decision is affected by different types of perceived risks. Xiang et al. (2012) submitted that parties involved in construction projects have been experiencing not only objective risks (e.g. policy risks) but also behavioural risks (e.g. uncooperative behaviours by other parties) which have a high possibility of damaging the relationship between parties. Hence, the contractor needs to deal with two types of risk concerning owner-contractor relationships: personal risk and performance risk. The in-house relations amongst the parties results in personal risks while the performance risks are comprised of the entire risks apart from the individual risk (Renuka, Umarani, \& Kamal, 2014).

The research of Sathishkumar, (2017) also showed that individuals with high levels of extroversion were inclined to engage in multiple, risky health behaviours and that extroverts can accept deviant acts more easily than introverts. Additionally, extroverts often take risks because of their generalized needs for sensation, which seems to be the goal of risk-taking behaviour. When facing multiple threats, extroverts will be at ease and perceive lower risk. Also, the experience was found to be closely related to how individuals see risk (Chauvin, Hermand, \& Mullet, 2007). The concepts of interest, intellectuality and open-mindedness are essential traits in this dimension (Chauvin et al., 2007). Also, individuals tend to understand some complex types of hazards better and thus view certain technological risk as less risky. Besides, individual differences like the desire to control and tolerate uncertainty are essential in predicting variables of risk perception (Jepson, Kirytopoulos, \& London, 2018).

Experience comprises the ability to demonstrate effective observation which has been gained through contribution and exposure to different issues in the process of working on various construction sites (Jayaram, Ahire, Nicolae, \& Ataseven, 2012). Agreeableness has nine facets according to the personality model offered by Goldberg (1999): understanding, warmth, morality, pleasantness, empathy, cooperation, sympathy, tenderness, and nurturance. It is closely related to the concepts of nonviolence, caring for others and the environment (Jayaram et al., 2012). Individuals with high agreeableness show more sympathy and empathy to others and thus tend to see some threats as undesirable. They tend to choose safer solutions or schemes to reduce their uncomfortable feelings. Evidence from studies suggests that more agreeable individuals are likely to often engage in less risky behaviour than others with risky-health behaviours. Therefore, it is assumed in this study that high levels of agreeableness would bring about high levels of risk perception. The character of contractors signifies a planned, skilful, strong-minded, and operative persona, as well as facets like dutifulness, carefulness, level-headedness, and neatness (Jayaram et al., 2012; Taofeeq et al., 2019).

Additionally, careful people tend to involve in a lesser amount of risky behaviour than other people. Thus, careful persons are likely to be balanced in hazardous circumstances and to make appropriate decisions in dangerous situations. They can likewise regulate their risk-taking propensities better. The emotional stability dimension has different facets, such as stability, calmness, impulse control, cool-headedness, and tranquillity. The spirit lies in the idea of boldness in many circumstances (Jayaram et al., 2012; Bamgbade et al.,2019). Emotionally steady personalities are less probable to be anxious or to understand risky or unwary actions. Therefore, due to the characters linked to steadiness and calmness, individuals will be more risk evading and thus identify high levels of risk. It is hence expected in this study that individuals with 
higher levels of emotional steadiness would observe higher levels of risk. (Dikmen, Birgonul, \& Gur, 2007). Competition and risk are two elements that are regularly used to designate the building business. Competition in a marketplace is brought about by numerous participants, who may perform otherwise under indeterminate situations dependent on their risk attitudes.

Therefore, Contractors' risk attitudes affect their bidding decisions in which they are exposed to uncertainties and competition. The competing contractors may have different risk attitudes that are part of their own organizational culture that has been developed over time. Different risk attitudes can explain the differences in how firms do their business. Heterogeneity in risk attitude and resultant variations in the ways they do business leads to questions about the relationships between risk attitude and project performance. In a risky situation, individuals perceive the situation in their ways, which are affected by their risk attitude. Organizational risk attitude is subconscious within an organization, but it defines what risks can be accepted and what risks cannot be accepted within an organization (Kim, et al., 2011; Planning et al., 2017; cha et al., 2012; Chun and Bing Bing 2016; Hassan et al., 2019).

Usually, most individuals and small groups challenged with a danger with possibly grave penalties are risk-averse in their attitudes. Also, companies or management agencies with large capitals are inclined to show a more risk-neutral attitude. The significance of risk-aversion in the policymaking process has been documented in the literature. Risk-averse decision-makers are inclined to misjudge likely losses and limit state likelihoods, particularly for low-probability risks that are outside the realm of their experiences. They may resist selecting an alternate decision which a traditional measurable risk valuation (e.g. minimum expected cost analysis) proposes is near-optimal and tend to pay higher costs to decrease the risk, particularly when personal injury is involved (Kim et al., 2011, Chun \& Bing Bing 2016; Waris et al., 2018).

According to Wang et al. (2011), men are generally less risk-averse than women. Contractors behave differently when dealing with small and large projects and when operating in good or bad periods. They are most times risk-averse toward larger projects in lean years and when the bid is relatively low. All of the studies mentioned above revealed that risk behaviour plays a central role in humans' decision making under uncertainty. It is, however, not surprising that previous research has mostly focused on how the risk attitude of decision-makers can vary under assumed risk situations represented by simple lotteries.

\subsection{The conceptual framework}

The Conceptual Framework describes how the variables (dependent and independent) identified in the study relate to each other. The independent variable affects and determines the effect of another variable. The independent variables in this study are Factors affecting risk attitudes; project-related factors, working capital, human-related factors and external environmental factors. The dependent variables are Contractors risk attitude; Risk-averse, Riskneutral, Risk-taker. The research investigates the top four leading factors among the eleven factors outlined in Table 1 and Figure 1 to develop the conceptual framework shown in Figure 2 that is empirically tested in the study.

\section{Independent Variables}

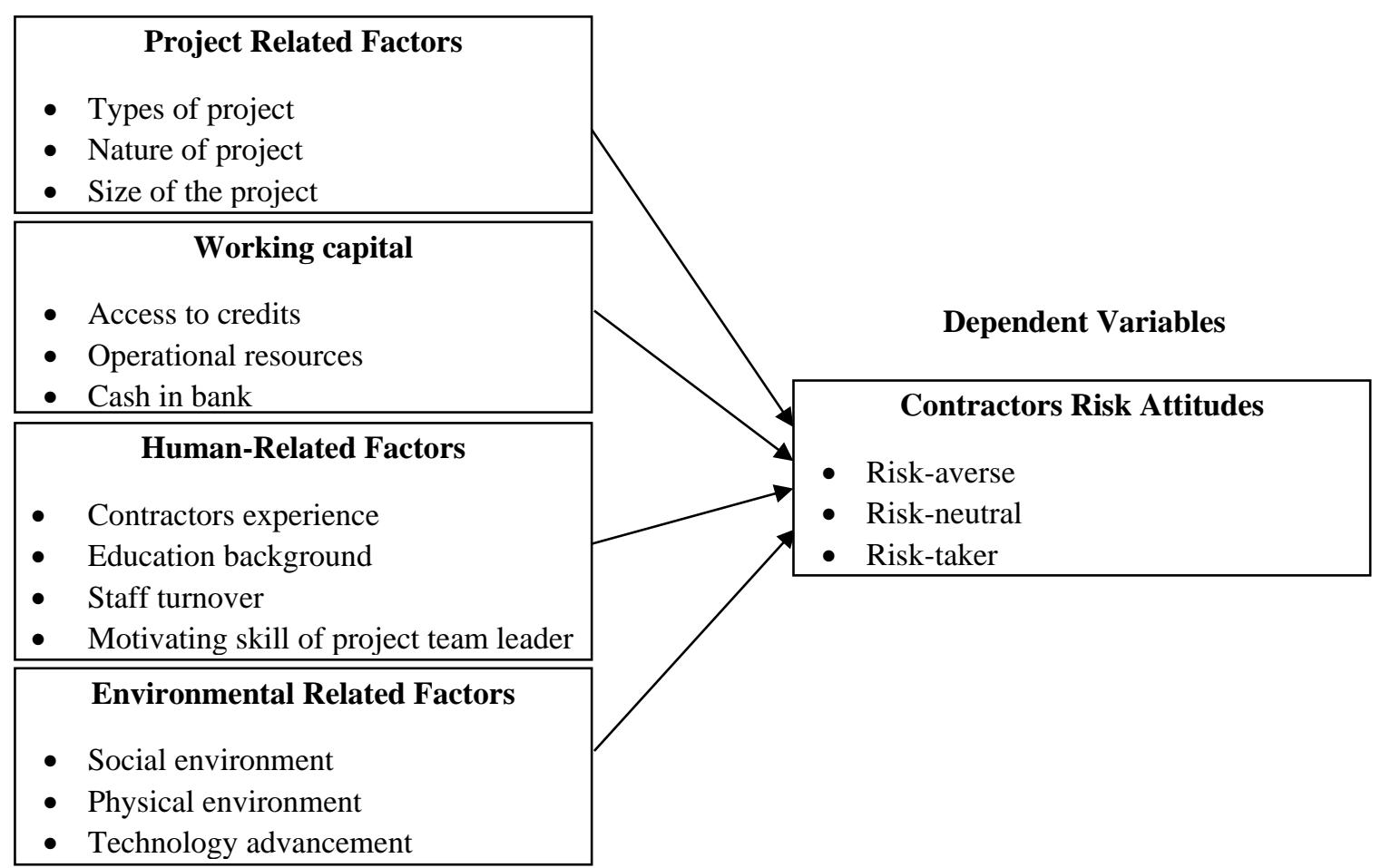

Figure. 2: Conceptual Framework 


\section{Methodology}

This study adopts a quantitative research approach employing a cross-sectional survey research design. The preliminary data for this research was collected through a literature review and the use of a questionnaire survey targeted at Grade 7 contractors (G7) and the team member operating in the Malaysian construction industry that specialises in building, bridge and road construction projects. There are seven categories of contractors in the Malaysian construction industry, which are; G1, G2, G3, G4, G5, G6 and G7. The G7 contractors were selected as a survey sample due to their ability to undertake large projects in Malaysia. The study ranked the specific factors affecting the contractor's risk attitudes in the Malaysian construction industry and answers the research question: What is the leading factor influencing the contractor's risk attitude in the Malaysian construction industry? The data collected were analysed with descriptive statistics. The demographic profile of the companies and respondents were examined.

\subsection{Scale of the questionnaire}

A Likert scale was used in quantifying the risk attitudes of contractors on a scale ranging from 1 to 6 (very low to very high). In this study, the selection of an interval scale mainly the 6-point scale is appropriate because it will increase the reliability of the data as well as lessen social desirability bias. According to Kulatunga and
Udayangani, (2006), Likert scales are proper and widely used in the attitudinal measurement.

\subsection{Response rate}

A total of 140 questionnaires were self-administered to the G\& contractors operating in the Malaysian construction industry. A total of 132 questionnaires were received after the survey period, representing a response rate of $94 \%$. Conversely, 13 questionnaires were found to be unusable due to missing data or provided the same responses to all the questions. Thus overall, $85 \%$ of the total questionnaires were found usable achieving an effective sample size of 119 .

\subsection{Reliability test}

There are various types of reliability test, "convergent validity, discriminant validity, indicator reliability" however, the most used method by the researchers is "internal consistency reliability test." Reliability is the magnitude to which items of a specific construct assemble and are autonomously capable of measuring the actual construct, and at the same time, the items are correlated with each other. The internal consistency reliability test of Cronbach's alpha coefficient (Sekaran \& Bougie, 2010) was adopted. As shown in Table 2, the results revealed that all measures achieved a high-reliability coefficient, ranging from 0.703 to 0.887 . A reliability coefficient of 0.60 is regarded as average reliability while a coefficient of 0.70 and above are considered as high reliability. Therefore, the result of this study meets the threshold of reliability (Hair et al., 2017; Sekaran \& Bougie, 2010).

Table 2: Summary of reliability results

\begin{tabular}{|c|c|c|c|}
\hline Constructs & Dimensions & No. of Items & Cronbach's Alpha \\
\hline \multirow{4}{*}{$\begin{array}{l}\text { Factors influence contractor's } \\
\text { risk attitudes. }\end{array}$} & Project related factors & 7 & .887 \\
\hline & Working capital & 7 & .794 \\
\hline & Human-related factors & 7 & .771 \\
\hline & Environmental related factors & 7 & .703 \\
\hline Contractor risk attitudes & $\begin{array}{l}\text { Risk-averse } \\
\text { Risk-neutral } \\
\text { Risk-taker }\end{array}$ & 9 & .737 \\
\hline
\end{tabular}

\section{Findings and Discussion}

\subsection{Demographic profile of the respondents}

The findings show that in terms of their gender, age, education, job position, working experience, company location, the respondents were constituted of $15(12.6 \%)$ female and $104(87.4 \%)$ males. The respondents are uniformly distributed across all age groups, age between $18-34$ are 47 (39.5\%), 35- 44 are $45(37.8 \%), 45-60$ are $21(17.6 \%)$ and above 60 are $(5.0 \%)$ respondents were 60 years above, whereas only four respondents contributed in this study were in-between 18 to 65 years of age.

The number of contractors that responded is 71 $(59.7 \%)$, contract managers are $11(9.2 \%)$, architects are $9(7.6 \%)$, project managers are $16(13.4 \%)$, and engineers are $12(10.1 \%)$. Regarding the qualification attained, the majority of the respondents $(65(54.6 \%))$ hold a master's degree, $32(26.9 \%)$ have a bachelor's diploma while 22 $(18.5 \%)$ have a PhD degree.
Concerning the experience level of the respondents, it was found that most of the respondents have moderate experience. A total of 53 with $(44.5 \%)$ of respondents have experience of 4 to 6 years, followed by 43 with $(36.1 \%)$, having less than 3 years, 15 with $(12.6 \%)$, having 7 to 9 years, and 8 with (6.7\%), having above 10 -year job experience.

Regarding job specialization and company location, more than half of the respondents 83 with (69.7\%) specialized on building projects, followed by 23 with $(19.3 \%)$ respondents specialized on the road project and only 13 with $(10.9 \%)$ of respondents are specialized on the bridge project. The respondents are located nationally across Malaysia are 50 (42.0\%), followed by 41 (34.5\%) located within few states in Malaysia, $21(17.6 \%)$ operate in the international market, and $7(5.9 \%)$ of the respondents operate in the local market area. 


\subsection{Ranking of factors affecting the contractors' risk attitude}

To determine the level of importance, the mean and standard deviation of each factor is derived from the total sample. If two or more factors happen to have the same mean value, the one with the lower standard deviation is considered more important. The factors with mean values that are greater than the average value of all mean values is classified as critical factors affecting contractors' risk attitudes. The ranking results of these factors are shown in Table 3.

Table 3: Ranking of factors affecting contractors' risk attitudes

\begin{tabular}{|l|c|c|c|}
\hline Factors & Mean & $\begin{array}{c}\text { Standard } \\
\text { Deviation }\end{array}$ & Rank \\
\hline Human-related factors & 3.7407 & .56656 & 1 \\
\hline Working capital & 3.5616 & .49852 & 2 \\
\hline Project related factors & 3.5798 & .60845 & 3 \\
\hline Environmental related factor & 3.4970 & .58425 & 4 \\
\hline
\end{tabular}

The results of the statistical analysis show that the overall mean and standard deviation for human-related factors is: 3.7407, Std: .56656, which makes human-related factors to be ranked first among all four specific factors affecting contractors' risk attitudes considered in this study. This is in line with the previous research of Wang et al. (2011), whose findings affirmed that human-related factors are not well implemented within construction companies.

Working capital is ranked as the second critical factor affecting contractors' risk attitudes with a mean value of 3.5616, Std: .49852. The main contributors to cost overrun in the procurement of high-rise in construction projects. Working capital also relating to interest rates, credit ratings, capital supply, cash flows and rentals. Local objects reliability risk arises because projects involve local partners such as contractors, customers, suppliers and the success of these projects depends on their reliability and affluence.

Project Related Factors was ranked third place based on the survey results with a mean value of 3.5798 , Std: .60845 , among all important factors. The result is in line with the findings of Wilden et al. (2013) who recommended that a prerequisite for high-quality project risk management is the ability to have access to required information relating to the handling of risk during particular project construction. If contractors have adequate and accurate information when making decisions against threats, they are probably willing to be

\section{References}

Abulhakim, N., \& Adeleke, A. Q. (2019). The Factors Contributing to Accident Occurrence on Malaysia Building Projects through Partial Least Square Structural Equation Modeling. Social Science and Humanities Journal, 1096-1106.

Adeleke, A. Q., Bahaudin, A. Y., Kamaruddeen, A. M., Bamgbade, J. A., Salimon, M. G., Khan, M. W. A., \& Sorooshian, S. (2018). The influence of organizational external factors on construction risk management among risk bearers, as they are confident and competent in making a good trade-off between risks and benefits. Otherwise, they cannot have the right perception of project risks or a clear understanding of the significant risks to their operation. The findings imply that taking a risk without adequate understanding and competence about that risk may lead to an unwillingness in bearing and managing the risk. Therefore, project professionals must develop their emotional intelligence since it has a direct impact on the effectiveness of risk management.

The Environmental Related Factors was ranked as the fourth critical factor affecting contractors' risk attitudes with this mean value: 3.4970 , Std: .58425 . The level of the risk is based on the probability of its occurrence, the possible severity of the risk, such as the population that may be affected and the health effects. Environmental risks comprise of natural disasters, weather, and seasonal implications.

\section{Conclusion}

This study has examined possible risks factors subcategorised based on their nature that impact contractors' risk attitude. This study is significant to all the relevant stakeholders in the construction industry. Furthermore, this study presents the ranking of the specific factors affecting contractors' risk attitudes in the Malaysian construction industry. Therefore, this research provides a ground for researchers with interest in this field, to further examine the relationships between the constructs in this study. This research provides a conceptual basis for understanding risk management in the construction industry. Contractors' risk attitudes are found to be influenced by human-related factors, working capital, project related factors and the external environment.

This study on factors influencing contractor risk attitudes is not the only essential to the academic world but also to the contractors, project managers, engineers who've required the controlling risk attitudes in every construction industry. Stakeholders in the construction industry can use the information in this research for developing a strategy on a contractor's risk attitude. Finally, this research is not without limitations. The data were collected through a questionnaire survey conducted in Malaysia Pahang, so the generalization of the findings should be made with caution. Future studies might carry out this research in other countries to ascertain if the results investigated in Malaysia will be similar.

Nigerian construction companies. Safety and Health at Work, 9(1), 115-124.

Adeleke, A. Q., Bahaudin, A. Y., \& Kamaruddeen, A. M. (2016). Preliminary analysis of organizational factors influencing effective construction risk management: A case study of Nigerian construction companies. Sains Humanika, 8(2).

Adeleke, A. Q., Nasidi, Y., \& Bamgbade, J. A. (2016). Assessing the Extent of Effective Construction Risk Management in Nigerian Construction Companies. Journal of Advanced Research in Business and Management Studies, 3(1), 1-10. 
Ajzen, I., \& Fishbein, M. (2000). Attitudes and the attitude-behavior relation: Reasoned and automatic processes. European review of social psychology, 11(1), 1-33.

Bamgbade J.A, M. N. M. Nawi, A. M. Kamaruddeen, A. Q. Adeleke \& Maruf Gbadebo Salimon (2019)Building sustainability in the construction industry through firm capabilities, technology and business innovativeness: empirical evidence from Malaysia, International Journal of Construction Management,DOI: 10.1080/15623599.2019.1634666

Barr, A., \& Feigenbaum, E. A. (Eds.). (2014). The handbook of artificial intelligence (Vol. 2). ButterworthHeinemann.

Chauvin, B., Hermand, D., \& Mullet, E. (2007). Risk perception and personality facets. Risk Analysis: An International Journal, 27(1), 171-185.

Chen, J., Chia, N., Kalari, K. R., Yao, J. Z., Novotna, M., Soldan, M. M. P., \& Weinshenker, B. G. (2016). Multiple sclerosis patients have a distinct gut microbiota compared to healthy controls. Scientific reports, 6, 28484.

Chun, Y., Tsai, C., \& Hsu, Y. (2016). Research on the operational performance of ISO 14000 Certified Taiwan's manufacturers. Asian Journal on Quality, 6(1), 24-34.

Culp, R. W., McGuigan, F. X., Turner, M. A., Lichtman, D. M., Osterman, A. L., \& McCarroll, H. R. (1993). Proximal row carpectomy: a multicenter study. The Journal of hand surgery, 18(1), 19-25.

Dikmen, I., Birgonul, M. T., \& Han, S. (2007). Using fuzzy risk assessment to rate cost overrun risk in international construction projects. International journal of project management, 25(5), 494-505.

Hassan, A. K., \& Adeleke, A. Q. (2019). THE Effects of Project Triple Constraint on Malaysia Building Projects. Social Science and Humanities Journal, 12221238.

Hanna, A., Boodai, F., \& El Asmar, M. (2013). State of the practice of building information modelling in mechanical and electrical construction industries. Journal of Construction Engineering and Management, 139(10), 04013009.

Hassan, A. K., Adeleke, A. Q., \& Hussain, S. (2019). Partial Least Square Structural Equation Modeling: An Approach to the Influence of Project Triple Constraint on Building Projects among Malaysian Construction Industries. Social Science and Humanities Journal, 14451464.

Hair, J. F., Hult, G. T. M., Ringle, C. M., Sarstedt, M., \& Thiele, K. O. (2017). Mirror, mirror on the wall: a comparative evaluation of composite-based structural equation modeling methods. Journal of the Academy of Marketing Science, 45(5), 616-632.

Hillson, D. \& Murray-Webster, R. (2007). Understanding and Managing Risk Attitude. Burlington, USA: Gower.

Hwang, B. G., Zhao, X., \& Toh, L. P. (2014). Risk management in small construction projects in Singapore: status, barriers and impact. International Journal of Project Management, 32(1), 116-124.

Jayaram, J., Ahire, S., Nicolae, M., \& Ataseven, C. (2012). The moderating influence of Product orientation on coordination mechanisms in total quality management.
International Journal of Quality \& Reliability Management, 29(5), 531-559.

Jaśkowski, P., \& Biruk, S. (2011). The Method for Improving Stability of Construction Project Schedules through Buffer Allocation: Statybos vykdymo grafiko stabilumo užtikrinimas paskirstant laiko rezervus. Technological and Economic Development of Economy, 17(3), 429-444.

Jarkas, A. M., \& Haupt, T. C. (2015). Major construction risk factors considered by general contractors in Qatar. Journal of Engineering, Design and Technology, 13(1), 165-194.

Jato-Espino, D., Castillo-Lopez, E., RodriguezHernandez, J., \& Canteras-Jordana, J. C. (2014). A review of application of multi-criteria decision making methods in construction. Automation in Construction, 45, 151-162.

Jepson, J., Kirytopoulos, K., \& London, K. (2018). Insights into the application of risk tools and techniques by construction project managers. International Journal of Construction Management, 1-19.

Khan, R. A., Liew, M. S., \& Ghazali, Z. B., (2014). Malaysian construction sector and Malaysia vision 2020: developed nation status. Procedia-social and behavioural sciences, 109.

Khan, K. S., Kunz, R., Kleijnen, J., \& Antes, G. (2003). Five steps to conducting a systematic review. Journal of the royal society of medicine, 96(3), 118-121.

Ke, Y., Wang, S., Chan, A. P., \& Cheung, E. (2009). Research trend of public-private partnership in construction journals. Journal of construction engineering and management, 135(10), 1076-1086.

Kim, H. J., \& Reinschmidt, K. F. (2011). Market structure and organizational performance of construction organizations. Journal of Management in Engineering, 28(2), 212-220.

Kulatunga, Udayangani, et al. (2006) "Attitudes and perceptions of construction workforce on construction waste in Sri Lanka." Management of Environmental Quality: An International Journal 17.1 (2006): 57-72.

Kim, B., Jung, S. H., Jang, S. H., Lee, B., Rhee, E., Cho, S. H., \& Lee, S. M. (2015). Construction and initial validation of the Planned Happenstance Career Inventory. The Career Development Quarterly, 62(3), 239-253.

Lee, C. K., Yiu, T. W., \& Cheung, S. O. (2016). Selection and use of alternative dispute resolution (ADR) in construction projects-past and future research. International Journal of Project Management, 34(3), 494507.

Lee, C. K., Yiu, T. W., \& Cheung, S. O. (2015). Perceived risks, obligations, and uncertainties: Antecedents of unpaid contractors' intention to suspend works against non-payment.Implementing Innovative Ideas in Structural Engineering and Project Management, ISEC 2015. ISEC Press.

Lu, Y., Li, Y., Skibniewski, M., Wu, Z., Wang, R., \& Le, Y. (2014). Information and communication technology applications in architecture, engineering, and construction organizations: A 15-year review. Journal of Management in Engineering, 31(1), A4014010.

Mhetre, Krantikumar, B. A. Konnur, and Amarsinh B. Landage. "Risk management in construction industry." Int. J. Eng. Res 5 (2016): 153-155. 
Planning, S. (2017). Risk Management Planning, Sustainability Risks Management, and Risk Stakeholders, 46(10), 1337-1348.

Project Management Body of Knowledge (PMBOK) a guide to the project management body of knowledge Project Management Institute, Newtown Square (PA) (2000).

Qudus, A. A. (2016). Construction risk management among construction companies in Nigeria: moderated by government regulation (Doctoral dissertation, Universiti Utara Malaysia).

Rahmat, N. I. (2016). Success factors for Bumiputra contractors in Malaysia: Johor State (Doctoral dissertation, Universiti Tun Hussein Onn Malaysia).

Razak Bin Ibrahim, A., Roy, M. H., Ahmed, Z., \& Imtiaz, G. (2013). An investigation of the status of the Malaysian construction industry. Benchmarking: An International Journal, 17(2), 294-308.

Renuka, S. M., Umarani, C., \& Kamal, S. (2014). A review of critical risk factors in the life cycle of construction projects. Journal of Civil Engineering Research, 4(2A), 31-36.

Sambasivan, M., \& Soon, Y. W. (2007). Causes and effects of delays in the Malaysian construction industry. International Journal of project management, 25(5), 517526.

Sathishkumar, V., Raghunath, P. N., \& Suguna, K. (2017). Critical Factors Influencing to Management Risk in Construction Projects. The International Journal of Engineering and Science (IJES) Volume, 4, 37-46.

Sekaran, U. \& Bougie, R. (2010). Research methods for business. A skill building approach (5th Ed.) John Willey: UK.

Shirodkar, V., \& Konara, P. (2017). Institutional distance and foreign subsidiary performance in emerging markets: Moderating effects of ownership strategy and host-country experience. Management International Review, 57(2), 179-207.

Taofeeq, D. M., Adeleke, A. Q., \& Hassan, A. K. (2019). Factors Affecting Contractors risk attitude from Malaysia construction industry perspective. Social Science and Humanities Journal, 1281-1298.
Taofeeq, D. M., Adeleke, A. Q., \& Lee, C. K. (2019). Individual factors influencing contractors' risk attitudes among Malaysian construction industries: the moderating role of government policy. International Journal of Construction Management, 1-20.

Taofeeq, D. M., Adeleke, A. Q., \& Hassan, A. K. (2019). The Moderating Role of Government Policy on Contractors' Risk Attitudes in Malaysia Construction Companies. Social Science and Humanities Journal, 1261-1280.

Toh, T. C., Ting, C., Ali, K. N., Aliagha, G. U., \& Munir, O. (2013). Critical cost factors for building construction projects in Malaysia. Procedia-Social and Behavioural Sciences, 57, 360-367.

Venkatesh, V., Brown, S. A., \& Bala, H. (2013). Bridging the qualitative-quantitative divide: Guidelines for conducting mixed methods research in information systems. MIS quarterly, 21-54.

Wang, J., \& Yuan, H. (2011). Factors affecting contractors' risk attitudes in construction projects: a Case study from China. International Journal of Project Management, 29(2), 209-219.

Wang, C. M., Xu, B. B., Zhang, S. J., \& Chen, Y. Q. (2016). Influence of personality and risk propensity on risk perception of Chinese construction project managers. International Journal of Project Management, 34(7), 1294-1304.

Waris, M., Khan, A., Ismail, I., Adeleke, A. Q., \& Panigrahi, S. (2018, April). Impact of leadership qualities on employee commitment in multi-project-based organizations. In IOP Conference Series: Earth and Environmental Science (Vol. 140, No. 1, p. 012094). IOP Publishing.

Wilden, R., Gudergan, S. P., Nielsen, B. B., \& Lings, I. (2013). Dynamic capabilities and performance: strategy, structure and environment. Long Range Planning, 46(12), 72-96.

Zhang, G.M., Wang, J.Y., 2015. Understanding the key risks in construction projects in China. International Journal of Project Management 25 (6), 601-614. 